\title{
PENGARUH METODE QUANTUM LEARNING YANG DIPADU DENGAN MIND MAP TERHADAP HASIL BELAJAR PENDIDIKAN AGAMA ISLAM
}

\author{
Oleh: Subiyono*
}

\begin{abstract}
This study aims at describing the influence of Quantum learning combined with Mind Map towards the outcome of Islamic education. This study is queasy-experiment with pretestposttest design, learning outcome by written test, and questionnaire. The data are analyzed by inferential statistic: covariate and percentage. The result shows that (1) there is no interactional influence between teaching model and pretest. (2) There is a significant influence of Quantum Learning method combined with Mind Map towards the achievement of Islamic Education. (3) Students have positive perception of the Quantum Learning combined with Mind Map in teaching Islamic Education, as it develops conducive learning condition.
\end{abstract}

KEYWORDS: Quantum learning, mind map, menyenangkan

PENDIDIKAN pada intinya adalah upaya sadar yang diberikan oleh pendidik dalam rangka membawa peserta didik kepada manusia ideal yang dicita-citakan. Bentuk manusia ideal yang dicita-citakan itu dirumuskan sendiri oleh suatu bangsa atau suatu komunitas.

Bagi bangsa Indonesia, manusia ideal yang ingin dibentuk tergambar dalam tujuan pendidikan nasional yang tercantum pada Undang-undang Nomor 20 Tahun 2003 Pasal 2, yaitu berkembangnya potensi peserta didik agar menjadi manusia yang beriman dan bertakwa kepada Tuhan Yang Maha Esa, berakhlak mulia, sehat, berilmu, cakap, kreatif, mandiri, dan menjadi warga negara yang demokratis serta bertanggung jawab. ${ }^{1}$

Dari rumusan tujuan di atas, kriteria manusia Indonesia yang ingin diciptakan itu mencakup: Pertama, manusia religius, manusia yang patuh dan taat menjalankan perintah agama. Kedua, manusia bermoral, berakhlak mulia, memiliki komitmen yang kuat terhadap kehidupan beretika. Ketiga,

*Magister Pendidikan Islam lulusan Program Pascasarjana UIN AlauddIn Makassar ini adalah guru mata pelajaran Pendidikan Agama Islam pada SMP Negeri 30 Semarang, Jawa Tengah. 
manusia pencari, penggali, pengamal ilmu pengetahuan, dan pecinta ilmu. Kelima, manusia yang memiliki kecakapan, sebagai perwujudan nyata dan aplikasi ilmu pengetahuan dalam kehidupan keseharian. Keenam, manusia yang kreatif. Ketujuh, manusia yang memiliki kemandirian, dengan sikap hidup dinamis penuh percaya diri serta memiliki semangat hidup yang dinamis. Kedelapan, kepedulian pada masyarakat bangsa dan negara, berjiwa demokratis dan rasa tanggung jawabnya yang tinggi untuk membawa bangsa Indonesia mencapai cita-cita idealnya. ${ }^{2}$

Kriteria tersebut merupakan tipe manusia ideal yang dibentuk oleh masyarakat Indonesia melalui wahana pengembangan potensi diri dalam proses pendidikan di sekolah. Akan tetapi, proses pembelajaran di sekolah terkadang belum mampu mengembangkan potensi peserta didik secara optimal. Selama ini proses pembelajaran di ruang-ruang kelas monoton. Akibatnya, peserta didik merasa bosan. Mereka duduk berjam-jam mencurahkan perhatian dan pikiran pada mata pelajaran. Belajar dirasakan sebagai beban yang memberatkan. Bobbi DePorter dan Mike Hernacki berpendapat, bahwa pada akhir sekolah dasar, kata "belajar" dapat membuat peserta didik merasa tegang dan terbebani, ${ }^{3}$ sehingga hari pertama masuk sekolah peserta didik masih malas untuk belajar.

Ketika peserta didik kurang bersemangat belajar, justru pendidik menggunakan metode pembelajaran yang kurang menarik perhatian. Eksistensi pendidik bukan sebagai fasilitator yang membelajarkan peserta didik, melainkan pribadi yang mengajar atau menggurui peserta didik. Bahkan, dalam penyampaian pesan pembelajaran, pendidik menggunakan media yang kurang interaktif dan atraktif. ${ }^{4}$ Dengan berjalannya semua ini, proses pembelajaran menjadi monoton dan membosankan.

Untuk mengatasi masalah di atas, Bobbi DePorter menawarkan Quantum Learning, seperangkat metode dan falsafah belajar yang terbukti efektif untuk semua umur. Metode tersebut menggunakan sugesti positif dalam proses pembelajaran dengan prinsip bahwa sugesti positif dapat dan pasti mempengaruhi situasi belajar. Beberapa teknik yang digunakan untuk memberikan sugesti positif antara lain: mendudukkan peserta didik secara nyaman, memasang musik latar di kelas, meningkatkan partisipasi individu, menggunakan poster-poster untuk memberi kesan belajar sambil menonjolkan informasi. ${ }^{5}$ Quantum Learning menggabungkan suggestologi, teknik pemercepatan belajar, program neurolinguistik, teori otak kanan/kiri, teori otak triune (3 in 1), pilihan modalitas (visual, auditorial dan kinestetik), teori kecerdasan ganda, pendidikan holistik (menyeluruh), belajar berdasarkan pengalaman, belajar dengan simbol (metaphorik learning) serta simulasi/permainan. ${ }^{6}$ 
Hasil penelitian Arni Arief Lamaka dan Chaerun Nisa tentang "Keefektifan Metode Quantum Learning terhadap Peningkatan Prestasi Belajar Siswa di LBB Gama College Makassar tahun 2002" menunjukkan bahwa sebagian besar peserta didik yang menjadi objek penelitian dapat meraih keberhasilan atau meningkat prestasinya. Hal itu di karenakan, lembaga ini menggunakan seperangkat metode Quantum Learning dalam proses pembelajaran seperti penataan ruangan yang nyaman, penyajian musik pada saat proses pembelajaran berlangsung, ada komunikasi yang baik dan penggunaan audio visual. Peneliti juga menyimpulkan, sebagian besar peserta didik di LBB Gama College Makassar menanggapi metode Quantum Learning sebagai salah satu bentuk pencapaian kualitas belajar yang potensial, karena mampu menciptakan belajar menjadi nyaman dan menyenangkan. ${ }^{7}$

Selain Quantum Learning, agar proses pembelajaran menyenangkan digunakan metode Mind Map untuk mencatat materi pembelajaran. Metode ini dikembangkan oleh Tony Buzan pada tahun 1970-an. Mind Map merupakan cara termudah untuk menempatkan informasi ke dalam otak dan mengambil informasi ke luar dari otak dengan membuat catatan yang kreatif dan efektif. 8 Mind Map merupakan alat yang membantu otak berpikir secara teratur, karena selalu menggunakan warna, memiliki struktur alami yang memancar dari pusat, menggunakan garis lengkung, simbol, kata dan gambar yang sesuai dengan satu rangkaian yang sederhana, mendasar, alami, dan sesuai dengan cara kerja otak. ${ }^{9}$

Teknik mencatat ini sangat dibutuhkan, dengan alasan: pertama, mencatat merupakan salah satu usaha untuk meningkatkan daya ingat; dan kedua, kebanyakan orang mengingat sangat baik ketika ia menuliskannya. Tanpa mencatat dan mengulanginya, kebanyakan orang hanya mampu mengingat sebagian kecil materi yang diajarkan.10 Apalagi pembelajaran dengan metode apapun tidak lepas dari kegiatan pencatatan. Begitu juga dalam Quantum Learning, peserta didik masih harus membuat catatan.

Oleh karena itu, Quantum Learning perlu dipadu dengan Mind Map. Quantum Learning merupakan metode pembelajaran yang menyenangkan, tetapi apabila peserta didik masih mencatat dengan catatan tradisional, maka pembelajaran menjadi membosankan. Sebab, pada umumnya peserta didik membuat catatan tradisional dalam bentuk tulisan linear panjang yang mencakup seluruh isi materi pelajaran, sehingga catatan terlihat sangat monoton dan membosankan. Apabila Quantum Learning dipadu dengan Mind Map, maka peserta didik tidak perlu membuat catatan dengan menggunakan format outline. 
Perbedaan antara catatan tradisional dengan Mind Map dijelaskan dalam tabel berikut ini: ${ }^{11}$

\footnotetext{
Catatan Tradisional

- Hanya berupa tulisan-tulisan saja

- Hanya dalam satu warna

- Untuk mereview ulang memerlukan waktu yang lama

- Waktu yang diperlukan untuk belajar lebih lama
}

- Statis

\author{
Mind Map (Peta Pikiran) \\ - Berupa tulisan, simbol, dan gambar \\ - Berwarna-warni \\ - Untuk mereview ulang diperlukan \\ waktu yang pendek \\ - Waktu yang diperlukan untuk belajar \\ lebih cepat dan efektif \\ - Membuat individu menjadi lebih \\ kreatif
}

Perpaduan antara Quantum Learning dengan Mind Map memungkinkan hasil belajar yang diperoleh menjadi komprehensif meliputi aspek kognitif, afektif, dan psikomotorik. Asumsi inilah yang mendasari diterapkannya Quantum Learning yang dipadu dengan Mind Map pada pembelajaran Pendidikan Agama Islam (PAI). Karena, salah satu karakteristik PAI bertujuan membentuk peserta didik agar memiliki akhlak mulia, ${ }^{12}$ sebagaimana misi utama diutusnya Nabi Muhammad saw. yaitu untuk menyempurnakan akhlak.

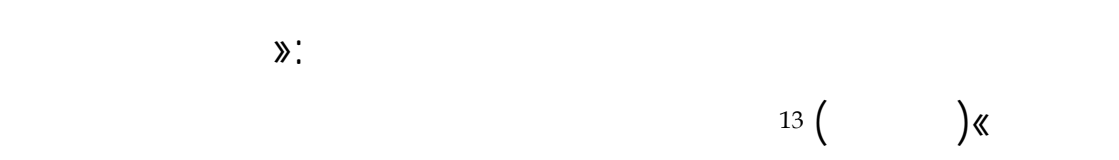

Dari Malik, sesungguhnya telah sampai kepadanya perkataan Rasul: "Aku diutus untuk menyempurnakan akhlak yang mulia".

Dengan demikian, mencapai akhlak yang mulia adalah tujuan sebenarnya dari PAI. Tetapi, karena dalam satu minggu peserta didik hanya menerima pembelajaran PAI selama 2 jam pelajaran atau selama 80 menit, dan kalau dipresentase hanya $0,79 \%$ dalam satu minggu, penghitungan ini didasarkan pada pembelajaran PAI selama 80 menit dalam setiap minggunya. 1 jam $=60$ menit, 1 hari $=24$ jam, 1 minggu $=7 \times 4 \times 60=10.080$ menit. Jadi persentase pembelajaran PAI selama satu minggu $=80 / 10.080 \mathrm{x}$ $100=0,79$. waktu selebihnya yaitu 99,21\% digunakan untuk pembelajaran bidang studi selain PAI dan kegiatan-kegiatan yang lainnya, maka dibutuhkan wadah untuk mempercepat pencapaian akhlak yang mulia tersebut. Salah satu di antaranya adalah penerapan Quantum Learning yang dipadu dengan Mind Map dalam pembelajaran PAI.

Dari uraian di atas, agaknya tidak terlalu berlebihan apabila diasumsikan bahwa ada karakteristik PAI yang cocok untuk dibelajarkan dengan 
Quantum Learning yang dipadu dengan Mind Map. Oleh karena itu, peneliti tertarik untuk mengujicobakan metode ini dalam pembelajaran PAI.

Selain menentukan Quantum Learning yang dipadu dengan Mind Map sebagai metode yang diujicobakan, peneliti juga memilih SMP Negeri 6 Makassar sebagai lokasi penelitian. Pemilihan tersebut didasarkan pada pertimbangan bahwa SMP Negeri 6 Makassar merupakan salah satu SMP di kota Makassar yang bernilai akreditasi A dengan No. Statistik Sekolah 201196007006. Akan tetapi, dalam kenyataannya proses pembelajaran PAI di SMP Negeri 6 Makasar belum diselenggarakan secara interaktif, inspiratif, menyenangkan, dan menantang. ${ }^{14}$ Akibatnya, PAI sering dipandang sebagai mata pelajaran yang menjemukan, sarat dengan dogma dan indoktrinasi norma-norma agama yang kurang membuka ruang bagi peserta didik untuk lebih kritis dan kreatif dalam proses pembelajaran. Tidak mengherankan jika kemudian peserta didik menjadi malas dan kurang bersemangat mengikuti mata pelajaran ini.

Oleh karena itu, penggunaan Quantum Learning yang dipadu dengan Mind Map pada pembelajaran PAI di SMP Negeri 6 Makassar, diharapkan mampu mengubah pandangan peserta didik terhadap PAI menjadi mata pelajaran yang menyenangkan, menumbuhkan minat, dan meningkatkan kreativitas peserta didik serta efektif dalam mencapai tujuan pembelajaran. Dengan pandangan tersebut, maka harapan akhirnya akan mempengaruhi hasil belajar PAI pada peserta didik di SMP Negeri 6 Makassar.

\section{METODE}

Penelitian ini merupakan penelitian quasi-experiment dengan pretestposttest control design. ${ }^{15}$ Sampelnya adalah peserta didik SMP 6 Kota Makassar tahun pelajaran 2008/2009 yang ditarik secara random dari kelas VIII yang memiliki grade menengah (kelas reguler). Variabel terikat yang diukur adalah hasil belajar PAI. Instrumen yang digunakan yaitu: (1) tes hasil belajar dalam bentuk soal pilihan ganda untuk mengetahui hasil belajar PAI, (2) angket untuk menghimpun data persepsi peserta didik terhadap metode pembelajaran yang diujicobakan. Data yang diperoleh dianalisis dengan statistik inferensial berupa analisis kovariat (ancova) dan analisis persentase.

\section{HASIL}

Berdasarkan hasil analisis data, maka dapat dikemukakan temuan penelitian berupa hasil belajar PAI sebagai akibat dari perlakuan metode pembelajaran yang digunakan sebagai berikut: 


\section{Hasil Belajar PAI}

Hasil analisis data menunjukkan bahwa: (1) nilai F interaksi antara model pembelajaran yang digunakan dengan kemampuan awal (pretest) peserta didik sebesar 0,147 dengan probabilitas 0,703 lebih besar dari 0,05 (signifikansi 5\%), ini berarti tidak ada pengaruh interaksi antara model pembelajaran yang digunakan dengan kemampuan awal (pretest) peserta didik terhadap hasil belajar PAI; (2) nilai F kelas perlakuan sebesar 9,610 dengan probabilitas 0,003 lebih kecil dari 0,05 (signifikansi 5\%), Ho ditolak. Jadi ada pengaruh perlakuan terhadap hasil belajar PAI; (3) kategori hasil belajar PAI peserta didik setelah dibelajarkan dengan Quantum Learning yang dipadu dengan Mind Map meningkat dari kategori kurang menjadi sangat baik untuk peserta didik yang berbeda kemampuan awalnya.

\section{Persepsi Peserta Didik}

Hasil analisis data menunjukkan bahwa: (1) 53,5\% responden menyatakan pembelajaran dengan Quantum Learning yang dipadu dengan Mind Map sangat nyaman dan menyenangkan, (2) $41 \%$ menyatakan cukup nyaman dan menyenangkan, (3) 4,6\% responden menyatakan kurang nyaman dan menyenangkan, (4) 0,9\% responden menyatakan tidak nyaman dan menyenangkan. Artinya, persepsi peserta didik terhadap model pembelajaran yang dikembangkan adalah positif dan mampu menciptakan belajar menjadi nyaman dan menyenangkan.

\section{PEMBAHASAN}

Peningkatan hasil belajar PAI yang dibelajarkan dengan Quantum Learning yang dipadu dengan Mind Map seperti temuan dalam penelitian ini sangat dimungkinkan. Alasannya adalah karena Quantum Learning merupakan seperangkat metode pembelajaran yang berprinsip bahwa peserta didik belajar lebih cepat, jika belajar menjadi kegiatan yang menyenangkan. ${ }^{16}$

Dave Meier sebagaimana dikutip Hernowo, mengatakan bahwa pembelajaran yang menyenangkan bukan berarti menciptakan suasana ribut dan hura-hura, tetapi menyenangkan di sini memiliki arti: bangkitnya minat, adanya keterlibatan penuh, terciptanya makna, adanya pemahaman atau penguasaan materi, dan munculnya nilai yang membahagiakan. ${ }^{17}$

Untuk menjadikan belajar menjadi menyenangkan, maka Quantum Learning mengembangkan beberapa teknik yaitu memasukkan tanaman ke dalam ruang kelas, menghias dinding dengan poster-poster indah dan tulisan-tulisan yang bermakna positif, mendudukkan peserta didik secara 
nyaman, menggunakan iringan musik dan Ice Breaker. Menurut Eric Jensen, ruangan kelas yang dilengkapi dengan tanaman tidak hanya menambah nilai estetika, ia juga menyediakan oksigen yang cukup bagi otak. ${ }^{18}$ Semakin banyak oksigen yang diperoleh oleh otak, semakin baik otak berfungsi. ${ }^{19}$

Poster-poster menarik dan tulisan bermakna positif yang ditempel di dinding kelas dimaksudkan agar dapat membangkitkan nafsu belajar peserta didik. Hal ini bisa terjadi, karena pada saat peserta didik memandang sekeliling ruangan, poster-poster tersebut seakan berdialog secara internal, sehingga menguatkan keyakinan tentang belajar dan isi yang pendidik ajarkan. ${ }^{20}$

Mendudukkan peserta didik secara nyaman dimaksudkan agar peserta didik tidak merasa bosan duduk berjam-jam di dalam kelas. Oleh karena itu, Quantum Learning berusaha mengatur meja/kursi disesuaikan dengan jenis interaksi yang diperlukan. Untuk presentasi, meja/kursi diatur sehingga peserta didik menghadap ke depan untuk membantu mereka tetap terfokus pada materi pembelajaran. Untuk kerja kelompok, meja/ kursi diputar saling berhadapan. ${ }^{21}$ Dengan cara demikian, kelas menjadi tempat yang nyaman dan menyenangkan untuk pembelajaran.

Penggunaan musik dalam pembelajaran, dimaksudkan untuk meningkatkan suasana hati dan membangun sebuah kondisi yang reseptif terhadap pembelajaran. ${ }^{22}$ Musik juga sangat mempengaruhi kondisi psikologis peserta didik. Selama melakukan pekerjaan mental yang melelahkan, tekanan darah dan denyut jantung cenderung meningkat. Gelombanggelombang otak meningkat dan otot-otot menjadi tegang. ${ }^{23}$ Dengan musik yang tepat memungkinkan denyut nadi dan tekanan darah menurun. Gelombang otak melambat, dan otot-otot menjadi rileks.

Sedangkan Ice Breaker dalam pembelajaran merupakan salah satu cara yang efektif untuk menghilangkan kejenuhan. Adi Soenaryo berpendapat, ketika peserta didik mulai bosan, mengantuk, jenuh, dan tidak tertarik saat mengikuti pembelajaran, diperlukan suatu cara untuk menghilangkan kejenuhan dan menarik perhatian mereka kepada pendidik dan materi yang disampaikan. Salah satu caranya adalah Ice Breaker. ${ }^{24}$ Ice Breaker yang tepat memungkinkan pembelajaran bisa diarahkan ke pencapaian tujuan. Selain itu, pembelajaran bisa menjadi lebih dinamis, tidak membosankan, menyegarkan, dan menyenangkan. Kesan menyenangkan pada proses pembelajaran merupakan modal utama untuk membuat pembelajaran menjadi lebih menarik.

Alasan berikutnya adalah karena Quantum Learning bekerja sesuai dengan sistem kerja otak. ${ }^{25}$ Otak manusia terbagi menjadi dua belahan, yaitu belahan kanan dan kiri bekerja secara sangat berbeda. Secara umum, otak kiri memainkan peranan dalam pemrosesan logika, kata-kata, mate- 
matika, dan urutan. Otak kanan berurusan dengan irama, ritme, musik, gambar dan imajinasi. ${ }^{26}$

Menurut DePorter, kedua belahan otak tersebut penting dan harus difungsikan secara seimbang. Apabila kedua belahan otak tersebut dimanfaatkan secara seimbang dalam pembelajaran, maka belajar terasa sangat mudah. ${ }^{27}$ Colin Rose dalam Gordon Dryden dan Jeanette Vos, mengilustrasikan: "Jika peserta didik mendengarkan sebuah lagu, otak kiri akan memproses syairnya dan otak kanan akan memproses musiknya. Jadi, bukanlah suatu kebetulan jika peserta didik memahami kata-kata dari lagu populer dengan begitu mudah. Dia tidak perlu berusaha keras untuk itu. Dia menghafalnya dengan cepat karena otak kiri dan otak kanan keduanya terlibat". 28

Dengan demikian, belajar dengan mengkoordinasikan otak kanan dan kiri membuat belajar menjadi sesuatu yang mudah. Model pembelajaran dalam bentuk inilah yang terdapat pada Quantum Learning yang ditunjukkan adanya unsur musik dan estetika dalam pembelajaran.

Alasan lainnya adalah karena Quantum Learning merupakan seperangkat metode yang dikembangkan dari berbagai konsep yang beranggapan bahwa peserta didik tidak hanya perlu belajar mengenai berbagai pengetahuan, tetapi juga perlu bagi peserta didik untuk "belajar cara belajar" (learning how to learn). Konsep belajar caranya belajar ini dapat membantu peserta didik untuk memahami materi yang diajarkan dengan lebih mudah dan efektif, serta mendukung peserta didik untuk belajar dengan lebih cepat dan menyenangkan, sehingga hasil belajarnya meningkat.

Oleh karena itu, dalam rangka penggunaan konsep belajar cara belajar, Quantum Learning mengembangkan keterampilan-keterampilan belajar seperti: meningkatkan kekuatan pikiran, menerapkan AMBAK (Apa Manfaat Bagi $\mathrm{Ku}$ ), menata lingkungan belajar yang nyaman, memupuk sikap positif, menemukan cara belajar yang tepat, meningkatkan teknik menulis, meningkatkan daya ingat, meningkatkan kemampuan membaca, dan membuat catatan yang efektif. ${ }^{29}$

Salah satu teknik mencatat yang terbukti cukup efektif adalah Mind Map. Teknik ini merupakan bentuk catatan yang tidak monoton, karena memadukan fungsi kerja otak secara bersamaan dan saling berkaitan satu sama lain sehingga akan terjadi keseimbangan kerja kedua belahan otak. Otak dapat menerima informasi berupa gambar, simbol, citra, musik dan lain-lain yang berhubungan dengan fungsi kerja otak kanan. ${ }^{30}$

Kenyataannya menunjukkan bahwa ketika peserta didik diberi pilihan untuk memilih mana yang disukainya antara belajar dan menonton 
film kartun, jawaban yang jujur akan menjawab film kartun yang lebih disukainya. Ini disebabkan, karena dalam sebuah film kartun selalu ada unsur gambar, warna, cerita (khayalan) dan emosi yang terlibat (senang, sedih, seru, bersemangat) di samping teks ceritanya. Gambar, warna dan cerita khayalan itulah unsur otak kanannya dan teks adalah unsur otak kirinya. ${ }^{31}$ Dengan demikian, otak kiri dan otak kanan pada saat bersamaan digunakan dua-duanya secara seimbang. Ini berarti bahwa, bila otak kiri dan otak kanan bekerja sama, kegiatan itu pasti menyenangkan.

Begitu juga seharusnya dengan strategi belajar peserta didik. Sungguh beruntung ada suatu "alat belajar" bernama Mind Map, yang selalu melibatkan kedua belah otak, sehingga dalam praktiknya semua Mind Map selalu menggunakan gambar, warna, garis lengkung, dan kata. Dan menurut Buzan, penggunaan gambar, warna, garis lengkung, dan kata dalam Mind Map semuanya memiliki makna. Sebuah gambar bermakna seribu kata dan membantu peserta didik dalam menggunakan imajinasi. Di samping itu, sebuah gambar juga membuat peserta didik tetap terfokus, membantu berkonsentrasi, dan mengaktifkan otak. Ihwal warna, bagi otak, warna sama menariknya dengan gambar. Warna membuat Mind Map lebih hidup, menambah energi kepada pemikiran kreatif, dan menyenangkan. Soal garis lengkung, Mind Map tidak menggunakan garis lurus, karena garis lurus akan membosankan otak. Cabang-cabang yang melengkung dan organis, seperti cabang-cabang pohon, jauh lebih menarik daripada garis lurus. Ihwal kata, Mind Map selalu menggunakan kata kunci, hal ini dikarenakan kata kunci memberi lebih banyak daya dan lebih bisa memicu ide dan pikiran baru. ${ }^{32}$

Bagaimana kemudian Mind Map memberi efek terhadap hasil belajar, Hernowo berpendapat, apabila peserta didik dapat menerapkan Mind Map ketika merekam materi pelajaran yang diperolehnya dari seorang pendidik atau sumber informasi lain, dia akan mampu mengingat dalam jangka waktu yang panjang. Di samping itu, peserta didik akan dapat dengan mudah membangkitkan rasa senangnya dalam belajar. Hal ini dikarenakan kedua belahan otak yang dimilikinya dapat bekerja secara optimal. ${ }^{33}$ Ini berarti, ketika peserta didik mampu mengingat dalam waktu yang lama dan merasa belajar menjadi sesuatu yang menyenangkan, maka hal ini akan berpengaruh terhadap pencapaian hasil belajar.

Asumsi inilah yang mendasari mengapa Quantum Learning perlu dipadu dengan Mind Map. Baik Quantum Learning maupun Mind Map memiliki prinsip bahwa belajar harus menjadi kegiatan yang menyenangkan dan berusaha untuk memanfaatan otak kiri dan otak kanan dalam proses pembelajaran. Adanya perpaduan Quantum Learning dengan Mind Map inilah yang memungkinkan hasil belajar peserta didik meningkat. 
Hasil belajar yang merupakan hasil dari suatu interaksi tindak belajar dan tindak mengajar ${ }^{34}$ dipengaruhi oleh dua faktor, yaitu: faktor Internal (yang berasal dari dalam diri) dan faktor eksternal (yang berasal dari luar).

Faktor yang datang dari dalam diri peserta didik meliputi kesehatan, inteligensi dan bakat, minat dan motivasi, serta cara belajar. ${ }^{35}$ Dari faktor tersebut, menurut penulis, yang mempunyai pengaruh besar terhadap peningkatan hasil belajar PAI kelas perlakuan adalah minat dan motivasi, serta cara belajar peserta didik.

Asumsi ini cukup beralasan karena minat belajar yang merupakan kecenderungan peserta didik untuk lebih bergairah dalam memperoleh pengalaman dan pengetahuan, ${ }^{36}$ dapat timbul karena daya tarik dari luar dan juga datang dari hati sanubari. Melalui pembelajaran Quantum Learning yang dipadu dengan Mind Map, peserta didik memiliki gairah yang besar dalam belajar, karena belajar menjadi kegiatan yang nyaman dan menyenangkan.

Motivasi juga besar pengaruhnya terhadap pencapaian hasil belajar peserta didik, karena motivasi menggerakkan, mengarahkan tindakan, serta memilih tujuan belajar yang dirasa paling berguna bagi kehidupan peserta didik. ${ }^{37}$ Pembelajaran Quantum Learning yang dipadu dengan Mind Map berusaha memotivasi individu yang menerapkannya dengan memanfaatkan AMBAK (Apa Manfaatnya BagiKu). Menurut DePorter, pemanfaatan AMBAK ini sama saja dengan menciptakan minat dalam belajar. Menciptakan minat seperti ini, merupakan jalan yang sangat baik untuk memotivasi diri demi mencapai tujuan. ${ }^{38}$

Demikian juga cara belajar, besar pengaruhnya terhadap pencapaian hasil belajar peserta didik. Dalam pembelajaran Quantum Learning yang dipadu dengan Mind Map, peserta didik memperoleh cara belajar yang baik. Salah satu keterampilan yang diajarkan adalah bagaimana membuat catatan yang efektif melalui Mind Map. Dengan Mind Map, peserta didik dapat mengatasi beberapa permasalahan belajar seperti tidak bisa konsentrasi, tidak paham apa yang dipelajarinya, dan mudah lupa apa yang sudah diingatnya. ${ }^{39}$

Adapun faktor dari lingkungan yang berpengaruh terhadap pencapaian hasil belajar peserta didik adalah lingkungan keluarga, sekolah, masyarakat, dan lingkungan sekitar. ${ }^{40} \mathrm{Di}$ antara faktor lingkungan yang dapat penulis analisis adalah lingkungan sekolah, karena lingkungan sekolah cukup dominan mempengaruhi hasil belajar peserta didik. Pendidik dan metode pembelajarannya, kesesuaian kurikulum dengan kemampuan peserta didik, keadaan fasilitas di sekolah, keadaan ruangan, jumlah peserta didik perkelas, pelaksanaan tata tertib, dan sebagainya, semua ini turut mempengaruhi keberhasilan belajar peserta didik. ${ }^{41}$ 
Pendidik dan metode pembelajarannya sangat mempengaruhi metode belajar yang dipakai oleh peserta didik. ${ }^{2}$ Dengan perkataan lain, metode pembelajaran yang dipakai oleh pendidik menimbulkan perbedaan yang berarti bagi pencapaian hasil belajar peserta didik.

Dengan demikian, penggunaan metode pembelajaran yang sesuai sangat menentukan keberhasilan belajar peserta didik. Melalui metode pembelajaran yang sesuai peserta didik dapat mencapai hasil belajar yang tinggi dan dapat mengembangkan potensi yang tersimpan dalam dirinya.

\section{PENUTUP}

Berdasarkan uraian tersebut di atas, penulis perlu mengemukakan kesimpulan dan memberikan saran sebagai berikut.

\section{Kesimpulan}

Kesimpulan penelitian ini adalah penggunaan metode Quantum Learning yang dipadu dengan Mind Map dalam pembelajaran PAI memberikan pengaruh yang signifikan terhadap pencapaian hasil belajar PAI.

\section{Saran-saran}

Beberapa saran yang dapat dikemukakan berdasarkan hasil atau temuan penelitian ini, antara lain:

1. Jika tujuan pembelajaran yang dilakukan adalah untuk meningkatkan hasil belajar PAI dan menciptakan pembelajaran yang menyenangkan, maka disarankan untuk menerapkan Quantum Learning yang dipadu dengan Mind Map.

2. Bagi pendidik, khususnya pendidik PAI hendaknya berupaya semaksimal mungkin untuk mengembangkan diri, meningkatkan kemampuan dan keterampilan serta memilih metode ini dalam pembelajaran PAI, karena metode ini mendapatkan tanggapan yang positif dari peserta didik.

3. Kepala sekolah dan penyelenggara pendidikan supaya senantiasa berusaha untuk menyiapkan terciptanya lingkungan belajar yang optimal bagi pembelajaran yang nyaman dan menyenangkan.

4. Berdasarkan pengalaman selama penelitian, disarankan agar dalam menerapkan metode ini musik yang digunakan adalah musik instrumental dan sedapat mungkin dikenal di dunia peserta didik.

5. Kepada peneliti yang berminat melanjutkan penelitian sejenis ini, agar meneliti variabel-variabel lain yang diduga cukup mempengaruhi hasil belajar PAI. 


\section{CATATAN AKHIR:}

1. Republik Indonesia, Undang-undang RI Nomor 20 Tahun 2003 tentang Sistem Pendidikan Nasional, Jakarta: CV. Mini Jaya Abadi, 2003, h. 5.

2. Haidar Putra Daulay, Pendidikan Islam dalam Sistem Pendidikan Nasional di Indonesia, Jakarta: Kencana, 2004, h. 198-199.

3. Bobbi DePorter dan Mike Hernacki, Quantum Learning: Unleashing the Genius in You diterjemahkan oleh Alwiyah Abdurrahman dengan judul Quantum Learning: Membiasakan Belajar Nyaman dan Menyenangkan, Bandung: Kaifa, 2002, h. 26.

4. Qowaid, "Meningkatkan Kualitas Pendidikan Agama melalui Inovasi Pembelajaran," dalam Choirul Fuad Yusuf (ed.), Inovasi Pembelajaran Pendidikan Agama Islam (SMP), Cet. I, Jakarta: PT. Pena Citrasatia dengan Puslitbang Pendidikan Agama dan Keagamaan, Badan Litbang dan Diklat Departemen Agama RI, 2007, h. 7.

5. Bobbi DePorter dan Mike Hernacki, Quantum Learning: Unleashing the Genius in You, h. 14.

6. Bobbi DePorter dan Mike Hernacki, Quantum Learning: Unleashing the Genius in You, h. 16.

7. Arni Arief Lamaka dan Chaerun Nisa, "Keefektifan Metode Quantum Learning terhadap Peningkatan Prestasi Belajar Siswa di LBB Gama College Makassar, (online), 2002, http://leoriset.blogspot.com/2008/06/ quantum-learning-melejitkan prestasi-html, diakses 23 Nopember 2008.

8. Tony Buzan, The Ultimate Book of Mind Map, dialihbahasakan oleh Susi Purwoko dengan judul Buku Pintar Mind Map, Jakarta: PT. Gramedia Pustaka Utama, 2008, h. 4.

9. Tony Buzan, The Ultimate Book of Mind Map, h. 5.

10. Bobbi DePorter dan Mike Hernacki, Quantum Learning: Unleashing the Genius in You, h. 146.

11. Iwan Sugiarto, Mengoptimalkan Daya Kerja Otak dengan Berfikir Holistik dan Kreatif, Jakarta: Gramedia Pustaka Utama, 2004, h. 76.

12. BSNP, Model Silabus dan Rencana Pelaksanaan Pembelajaran: Mata Pelajaran Pendidikan Agama Islam SMP/MTs, Jakarta: Departemen Pendidikan Nasional, 2006, h. 2.

13. Imam Malik ibn Anas, al-Muwatta', Beirut: Dar al-Jail, 1993, h. 789.

14. M. Nasir, Guru Pendidikan Agama Islam (PAI) SMP Negeri 6 Makassar, Wawancara, tanggal 1 Nopember 2008, di SMP Negeri 6 Makassar.

15. Nana Syaodih Sukmadinata, Metode Penelitian Pendidikan, Bandung: PT. Remaja Rosdakarya, 2007, h. 207.

16. Jalaluddin Rahmat, Belajar Cerdas: Belajar Berbasiskan Otak, Bandung: Mizan Learning Center, 2006, h. IX.

17. Hernowo, Menjadi Guru yang Mau dan Mampu Mengajar secara Menyenangkan, Bandung: Mizan Learning Center, 2008, h. 49-53.

18. Eric Jensen, Brain-Based Learning: The New Science of Teaching \& Training, Revised Edition, diterjemahkan oleh Narulita Yusron dengan judul Brain-Based Learning: Pembelajaran Berbasis Kemampuam Otak Cara Baru dalam Pengajaran dan Pelatihan, edisi revisi, Yogyakarta: Pustaka, 2008, h. 103. 
17. Bobbi DePorter, et al. Quantum Teaching: Orchestrating Student Success diterjemahkan oleh Ary Nilandari dengan judul, Quantum Teaching: Mempraktekkan Quantum Learning di Ruang-ruang Kelas, Bandung: Kaifa, 2002, h. 6.

18. Bobbi DePorter, et. al. Quantum Teaching: Orchestrating Student Success, h. 69.

19. Bobbi DePorter, et. al. Quantum Teaching: Orchestrating Student Success, h. 70.

20. Eric Jensen, Brain-Based Learning: The New Science of Teaching \& Training, h. 388.

21. Bobbi DePorter dan Mike Hernacki, Quantum Learning: Unleashing the Genius in You, h. 72.

22. Adi Soenarno, Ice Breaker: Permainan Atraktif-Edukatif untuk Pelatihan Manajemen, Yogyakarta: Andi Offset, 2007, h. 1-2.

23. Agus Nggermanto, Quantum Quotient (Kecerdasan Quantum): Cara Cepat melejitkan IQ, EQ, dan SQ secara Harmonis, Bandung: Nuansa, 2008, 31.

24. Gordon Dryden dan Jeanette Vos, The Learning Revolution; to Change thew Way the World Learn, Canada: The Learning Web, 1999, h. 125.

25. Bobbi DePorter dan Mike Hernacki, Quantum Learning: Unleashing the Genius in You, h. 72.

26. Gordon Dryden dan Jeanette Vos, The Learning Revolution; to Change thew Way the World Learn, h. 125.

27. Bobbi DePorter dan Mike Hernacki, Quantum Learning: Unleashing the Genius in You, h. 12.

28. Bobbi DePorter dan Mike Hernacki, Quantum Learning: Unleashing the Genius in You, h. 152.

29. Sutanto Windura, Mind Map Langkah demi Langkah: Cara Paling Mudah dan Benar Mengajarkan dan Membiasakan Anak Menggunakan Mind Map untuk Meraih Prestasi, Jakarta: PT. Elex Media Komputindo Kelompok Gramedia, 2008, h. 13.

30. Tony Buzan, The Ultimate Book of Mind Map, h. 15.

31. Hernowo, Vitamin T: Bagaimana Mengubah Diri Lewat Membaca dan Menulis, Bandung: Mizan Learning Center, 2004, h. 135-136.

32. Dimyati dan Mudjiono, Belajar dan Pembelajaran, Jakarta: Pusat Pembukuan Departemen Pendidikan dan Kebudayaan dan Rineka Cipta, 2006, h, 3.

33. M. Dalyono, Psikologi Pendidikan, Jakarta: PT. Rineka Cipta, 2006, h. 55.

34. Muh. Surya, Psikologi Pendidikan, Bandung: FIP IKIP, 1979, h. 79.

35. Abu Ahmadi dan Widodo Supriyono, Psikologi Belajar, Jakarta: PT. Rineka Cipta, 1991, h. 139.

36. Bobbi DePorter dan Mike Hernacki, Quantum Learning: Unleashing the Genius in You, h. 51.

37. Sutanto Windura, Mind Map Langkah demi Langkah: Cara Paling Mudah dan Benar Mengajarkan dan Membiasakan Anak Menggunakan Mind Map untuk Meraih Prestasi, h. 7.

38. M. Dalyono, Psikologi Pendidikan, h. 59.

39. M. Dalyono, Psikologi Pendidikan, h. 24.

40. M. Dalyono, Psikologi Pendidikan, h. 24.

\section{DAFTAR PUSTAKA:}

Ahmadi, Abu dan Widodo Supriyono, Psikologi Belajar, Jakarta: PT. Rineka Cipta, 1991. 
BSNP, Model Silabus dan Rencana Pelaksanaan Pembelajaran: Mata Pelajaran Pendidikan Agama Islam SMP/MTs, Jakarta: Departemen Pendidikan Nasional, 2006.

Buzan, Tony, The Ultimate Book of Mind Map, dialihbahasakan oleh Susi Purwoko dengan judul Buku Pintar Mind Map, Cet. VI; Jakarta: PT. Gramedia Pustaka Utama, 2008.

Dalyono, M., Psikologi Pendidikan, Cet. I; Jakarta: PT. Rineka Cipta, 2006.

Daulay, Haidar Putra, Pendidikan Islam dalam Sistem Pendidikan Nasional di Indonesia, Cet. I; Jakarta: Kencana, 2004.

DePorter, Bobbi, dan Mike Hernacki, Quantum Learning: Unleashing the Genius in You diterjemahkan oleh Alwiyah Abdurrahman dengan judul Quantum Learning: Membiasakan Belajar Nyaman dan Menyenangkan, Bandung: Kaifa, 2002.

DePorter, Bobbi et. al, Quantum Teaching: Orchestrating Student Success diterjemahkan oleh Ary Nilandari dengan judul, Quantum Teaching: Mempraktekkan Quantum Learning di Ruang-ruang Kelas, Bandung: Kaifa, 2002.

Dimyati dan Mudjiono, Belajar dan Pembelajaran, Jakarta: Pusat Pembukuan Departemen Pendidikan dan Kebudayaan dan Rineka Cipta, 1999.

Dryden, Gordon dan Jeanette Vos, The Learning Revolution; to Change thew Way the World Learn, Canada, The Learning Web, 1999.

Hernowo, Vitamin T: Bagaimana Mengubah Diri Lewat Membaca dan Menulis, Cet. I; Bandung: Mizan Learning Center, 2004.

-------, Menjadi Guru yang Mau dan Mampu Mengajar secara Menyenangkan, Cet. VIII; Bandung: Mizan Learning Center, 2008.

Jensen, Eric, Brain-Based Learning: The New Science of Teaching $\mathcal{E}$ Training, Revised Edition, diterjemahkan oleh Narulita Yusron dengan judul Brain-Based Learning: Pembelajaran Berbasis Kemampuam Otak Cara Baru dalam Pengajaran dan Pelatihan, Edisi revisi, Cet. I; Yogyakarta: Pustaka, 2008.

Lamaka, Arni Arief dan Chaerun Nisa, Keefektifan Metode Quantum Learning terhadap Peningkatan Prestasi Belajar Siswa di LBB Gama College Makassar 2002, [http://leoriset.blogspot.com/2008/06/quantum-learning-melejitkan prestasi-htmll, diakses 23 Nopember 2008.

Malik, Imam ibn Anas, al-Muwatta', Bairut: Dar al-Jail, 1993.

Nasir, Guru Pendidikan Agama Islam (PAI) SMP Negeri 6 Makassar, Wawancara, tanggal 1 Nopember 2008, di SMP Negeri 6 Makassar.

Nggermanto, Agus Quantum Quotient (Kecerdasan Quantum): Cara Cepat melejitkan IQ, EQ, dan SQ secara Harmonis, Cet. VII; Bandung: Nuansa, 2008.

Qowaid, "Meningkatkan Kualitas Pendidikan Agama melalui Inovasi Pembelajaran," dalam Choirul Fuad Yusuf (ed.), Inovasi Pembelajaran Pendidikan Agama Islam (SMP), Cet. I; Jakarta: PT. Pena Citrasatia dengan Puslitbang Pendidikan Agama dan Keagamaan, Badan Litbang dan Diklat Departemen Agama RI, 2007.

-------, Belajar Cerdas: Belajar Berbasiskan Otak, Bandung: Mizan Learning Center, 2006.

Soenarno, Adi, Ice Breaker: Permainan Atraktif-Edukatif untuk Pelatihan Manajemen, Yogyakarta: Andi Offset, 2007.

Sugiarto, Iwan, Mengoptimalkan Daya Kerja Otak dengan Berfikir Holistik dan Kreatif, Jakarta: Gramedia Pustaka Utama, 2004. 
Sukmadinata, Nana Syaodih, Metode Penelitian Pendidikan, Bandung: PT. Remaja Rosdakarya, 2007.

Surya, Muh., Psikologi Pendidikan, Bandung: FIP IKIP, 1979.

Windura, Sutanto, Mind Map Langkah demi Langkah: Cara Paling Mudah dan Benar Mengajarkan dan Membiasakan Anak Menggunakan Mind Map untuk Meraih Prestasi, Jakarta: PT. Elex Media Komputindo Kelompok Gramedia, 2008. 